Ігор ОПАЦЬКИЙ,

orcid.org/0000-0002-6786-3295

викладач кафедри історії України

Уманського державного педагогічного

Університету імені Павла Тичини

(Украӥна, Умань)

igor.opatskiy@gmail.com

\title{
ІСТОРИКО-АРХЕОЛОГІЧНИЙ НАРИС ПЕТРА КУРІННОГО «МІСТО ГУМАНЬ»: ПОВЕРНЕННЯ ДО ЧИТАЧА. Ч. 2
}

\begin{abstract}
Стаття є продовженням публікащії історико-археологічного нарису з історії міста Умань «Місто Гумань» відомого українського археолога, історика, засновника Уманського краєзнавчого музею, одного з ініціаторів створення Украӥнської вільної академії наук - П. Курінного. До уваги читачів запропоновано третю $i$ четверту частини нарису Петра Курінного, щэо опублікований 1952-1953 рр. в 4-х частинах діаспорного журналу «Авантард». Наведені в даній публікації 3 i 4 частини нарису містять оригінальне бачення історії краю та знайомлять із найважливішими подіями історї Уманщини XVIII - перших десятиліть XX ст. Особливу увагу автор звертає на розвінчування тверджень польської історіографії про Коліївщчиу в Умані, а також на культурне життя краю напередодні більшовицької окупачії.
\end{abstract}

Ключові слова: Умань, Петро Курінний, краєзнавство, Колї̈вщина, украӥнська діаспора.

Ihor OPATSKIY, lecturer of History of Ukraine Chair Pavlo Tychyna Uman State Pedagogical University

(Ukraine, Uman) igor.opatskiy@gmail.com

\section{HISTORICAL AND ARCHAEOLOGICAL ESSEY OF PETRO KURINNYI «CITY OF GUMAN»: RETURN TO READERS. Part 2}

Petro Kurinnyi's social activity and scientific work had been analyzed in the article. The main scientific achievements of the scientist in emigration were highlighted. The first archaeological excavations of Petro Kurinnyi and his formation as an archaeologist had been explored. The attention was also payed to the teacher of the history and geography of Uman Man's Gymnasium Danylo Shcherbakivskyi in his promoting the admiration of archeology and ethnography among students.

The author stated, that the first excavations on the territory of the Uman region, $P$. Kurin began while studying in the gymnasium. The study of the historical past of the Uman region had become much more active since 1913, when the Uman branch of the Kyiv Society for the Protection of Antiquities and Art appeared in Uman, and P. Kurinnyi was its member. Together with other members of the society P. Kurinnyi carried out archaeological excavations of the remains of the burial mounds in Kocherzhyntsi village. During these excavations, human remains, remnants of ceramics and metal jewelry were found.

Being a student, Petro P. Kurinnyi started conducting a special archaeological research of the Uman region. The beginning of the pedagogical and cultural activity of Petro P. Kurinnyi after the university graduation in 1917 has been highlighted. In addition to teaching in several Uman schools, the young teacher co-ordinated the work of the restored local history circle, and together with his students he collected antiquities, which became the basis for $P$. Kurinnyi's creation of the "Social and Historical Museum of Uman".

The basic directions of scientific establishments' activity where P. Kurinnyi took an active participation, had been shown. The main scientific achievements of the scientist in emigration were highlighted. Collaboration with the Institute for the Study of the USSR had being analyzed. The Ukrainian editorial board of the Institute was headed by P. Kurinnyi and in the course of 10 years, in collaboration with a talented group of researchers, he edited 17 volumes of 
scientific works entitled «Ukrainian Collection». The scientific path of a scientist in the Ukrainian Free University, administrative positions and main works, prepared by $P$. Kurinnyi for publication, had been indicated.

The first two parts of the historical and archeological essay of Petro Kurinnyi on the history of Uman "City of Guman», published in 1952-1953 in four parts in the diaspora magazine "Avangard» had been analyzed. The parts of the mentioned essay contained an original view of the history of the region's settlement and introduced the most important events of the history of Uman from ancient times to the beginning of Haydamak rebelions.

Thus, we conclusion that the results of archaeological excavations of P. Kurinnyi in the Uman region from 1912 to the beginning of the 1930's were a significant contribution to the study of the region's past. Significant contributions had been made to the study of the settlements of Trypillian culture in the villages of Uman region.

Key words: Uman, Petro Kurinnyi, regional studies, Koliivshchyna, Ukrainian emigrations.

Постановка проблеми. У попередньому номері видання ми знайомили читачів 3 першими двома частинами історико-археологічного нарису Петра Курінного «Місто Гумань», в яких на основі історико-археологічних досліджень було викладено погляди автора на історію міста 3 найдавніших часів до доби руїни. Червоною лінією через попередні частини нарису проходить тема, що з найдавніших часів Уманщина була густо заселеною територією, а в часи енеоліту - центром Трипільської культури. Автор наголошує на спадкоємності традицій та звичаїв трипільців українським народом. В добу раннього залізного віку Уманщина «мала спільну етнічноєдину культуру, міста й широкі зв'язки» з сусідніми регіонами, а в часи Київської Русі Уманщина мала назву «Куманія» та була «столицеюзимовищем» половців-куманів.

Окрему увагу П. Курінний приділяв історії та культурі Уманщини XIV XV ст. $з$ метою показати, що цей край напередодні колонізації поляками був не «пустелею», а «полем діяльності видатних українських князів (СвятополкаЧетвертинського, Острожських тощо)».

У третій і четвертій частині нарису П. Курінний подав інформацію про основні історичні події та культурне життя краю з XVIII до перших десятиліть $\mathrm{XX} \mathrm{ст.}$

Аналіз досліджень. На сьогодні дослідниками зроблено чимало у вивченні біографії П. Курінного. Основні віхи професійної та наукової біографії П. Курінного знайшли відображення у публікації С. Білоконя (Білоконь, 1998). Значний масив листування П. Курінного 3 колегами та рідними, насамперед батьком, введено до наукового обігу Г. Станиціною 
(Станіцина, 2015). Ю. Торгало збагатив біографічні відомості про П. Курінного, опублікувавши частину матеріалів з родинного архіву Курінних (Торгало, 2014). Л. Пекарська окреслила основні напрямки діяльності П. Курінного у науковому житті української еміграції (Пекарська, 2009).

Виклад основного матеріалу. Після еміграції в 1943 р. до Німеччини П. Курінний продовжив займатися науковою діяльністю та став членом низки наукових інституцій української діаспори: Український Вільний Університет, НТШ, УВАН, Науково Дослідний Інститут Української Мартирології, Українське Історичне Товариство, Інститут з вивчення СРСР та ін. Зібраний раніше історичний матеріал про Умань став основою для публікації у 195253 рр. у чотирьох номерах журналу Союзу Української Молоді «Авангард» ${ }^{1}$, у рубриці «Містами України», науково-популярного нарису з історії міста Умані «Місто Гумань». Цей нарис містить оригінальний погляд на минувшину нашого міста та кілька дискусійних тверджень. Однак не відомий для широкого кола вітчизняних дослідників. Тому пропонуємо ознайомитися 3 третьою та четвертою частиною нарису і запрошуємо до дискусії. Текст нарису публікуємо мовою оригіналу зі збереженням стилістичних та орфографічних особливостей.

\section{П. Курінний Містами України. Місто Гумань. Гайдамачина}

(продовження з попереднього числа) (Курінний, 1952).

XVIII ст. на Україні - це продовження нищення старих надбань українського народу двома змовниками - Польщею і Московією. Кожний $з$ цих змовників хотів урвати собі з України найбільше земель з людьми. Люди бо єдино забезпечити могли своєю працею і податком прибутковість земель. Кожний з хижаків хотів обдурити свого спільника, позалаштунково робив підступи, шкоди та підбурював сусідів один на одного. Але на чому сходилися усі, це на тому, що Україну можна знищити лише, поділивши iï на частини,

\footnotetext{
1 Журнал «Авангард» - орган Спілки Української Молоді (СУМ). Почав виходити 31946 р. у м. Мюнхен. В різний період часу головними редакторами журналу були П. Кізко, П. КарпенкоКриниця, М. Кушнір, В. Шульга, Г. Наняк, О. Калинник, І. Крушельницький, В. Леник, Р. Зварич, О. Рожка. На сторінках видання публікувалися науково-популярні праці з українознавства, проблем виховання, подавалася інформація та хроніка з діяльності СУМ, розповідалося про визвольну боротьбу українського народу.
} 
розколовши іï міць на взаємне поборювання. Для того різними провокаціями бойові сили України включалися у власні сили нападників і за їх спиною, їх руками зміцнювався грунт загарбників (всяких губернаторів, старост, генералів тощо). Так було в XVII ст., так продовжувалось і в XVIII ст. Коли гетьман Іван Мазепа року 1704-го фактично досяг об'єднання України під своєю булавою, цар Петро І-ий наказав йому віддати полякам Білу Церкву, а самому забратися геть з Правобережної України. Для царя таємна угода про розподіл України діяла сильніш, ніж щасливий випадок поєднання України. Але успішному здійсненню домовленості змовників перешкоджав український народ і його лицарство - козаччина. Гуманщина в цих визвольних рухах була на чолі.

Дуже повчальним епізодом під цим поглядом є український визвольний народній рух, що має назву Гайдамаччина або Коліївщина, що знайшла своє завершення, кінцеву фазу на Уманщині в формі т. зв. Уманської різні, спровокованої Москвою та Польщею. В ній загинуло від руки повсталого народу багато невинних людей, разом, правда, зі справжніми винуватцями 3 численними польськими катами-адміністраторами та емісарами.

Про події Уманської різні маємо два джерела пізнання фактів іï: 1. мемуари, описи, літературні твори, літописи, записки тих, що постраждали (в даному разі тих, що так або інакше належали «винним» і «потерпілим») та 2. народні оповідання, поезії, записки, що в ідеалізованій формі від імені «скривджених» рисують події в ідеальній, а не реальній формі, поминаючи темні сторони подій. В залежності від того, на які з цих джерел спирається історик в своєму дослідженні, виникають різні концепції історичного освітлення подій і різні погляди.

3 першоджерел, які знаємо для пізнання уманської різні з боку потерпілих, можемо назвати такі:

1. Молитву-елегію пам'яті загиблих жидів 1768 р., що читалася в синагогах Уманщини в день річниці подій. В ній описано страждання жидів в ці дні. 
2. Мемуари дочки губернатора Младоновича Вероніки Кребс, двох безіменних мемуаристів.

3. Записки Ліпомана, Тучапського, П. Младановича, Мошинського.

4. Книга суда Коденського, що судив Івана Гонту і Гайдамаків та протоколи слідства, ведені регіментарем Стемпковським.

5. Ордери й рапорти полковника Уманського Ортинського, що грабував селян і купців при переїзді їх через кордон і складав донесення про дії гайдамаків.

6. Ордери російських губернаторів і емісарів 3 архіву фортеці св. Елізавети (Слісаветград) та київського губернатора.

На підставі цих джерел в польській та російській історіографії та громадській опінії склався погляд про страшні злочини козаччини, гайдамаків та знущання над мирним населенням в Гумані, що підтримується в політичних цілях і досі.

3 боку гайдамацького і народного джерелами є:

1. Народні пісні, думи й легенди про гайдамаків, що показують народні погляди на діячів громадського руху i священної боротьби за визволення;

2. Оповідання очевидців, зокрема «діда Курінного» - козака, що був в Умані і врятував дочку губернатора Младановича від смерті, яке записав i видав М. Грабовський під назвою: «Opowidania dida Kurinnego»

3. У Українські літописи того часу;

4. Фолькльорний матеріял з часу Гайдамаччини, записаний Тарасом Шевченком в поемі «Гайдамаки»;

5. Архівні джерела про місто Умань, стародавні плани м. Умані, що дають об'єктивне тло для зрозуміння основних причин гайдамацького руху i участі в ньому Москви, Польщі та запоріжців;

6. Матеріяльні пам'ятки, зокрема архітектурні, що дають рамки, в яких ці історичні події відбувалися. 
От як визначає польський історик I. Чарновський (1854 р.) в праці «Ukraina i Zaporoze, czyli Historia Kozakow» причини і перебіг цього інциденту в ряді низки інших історичних конфліктів українського народу зі своїми соціяльними і національними гнобителями, що відбулись на протязі довгих віків ще задовго до 1569 р. та 1768 р. Це свідчення для нас є особливо важливим, бо факти уманської різні подані так, як вони зафіксувалися очам поляка-спостерігача, ворожого Україні. Візьмемо цитати 3 праці I. Чарновського: «Коли Західня Україна була повернута Польщі (з 1714 р.) і пани розібрали поміж себе іï маєтності, тоді багато козаків перенеслося на лівий берег Дніпра, інші залишалися як піддані магнатів» (стор. 299).

«Цар Петро поширив свою опіку , над православними» (стор. 299).

«Жадібні намісники панів під покровом ретельности релігійної гнітили люд, вперто прив'язаний до віри своїх батьків, оббирали його, наїздили на нього, грабували, мучили», (стор. 299).

«Маршалок Пулавський, взявши полк кавалерії, навербував шляхти i увійшов до староства чигиринського, навертаючи люд до унії збройною рукою». (стор. 300).

«М. Яворський, архимандрит чигиринський в імени духівництва чигиринського вдався до єпископа Гервасія Переяславського (тоді московської юрисдикції (П.К.), просячи благословення на повстання, яке було йому уділене» (стор. 301).

«Мельхиседек дав Залізнякові грамоту, написану золотими буквами, що названа була людьми «золотою грамотою» (в якій цариця закликала людей до повстання і обіцяла свою допомогу) (стор. 301).

«Банда назвала Залізняка своїм полковником і подалася дорогою Жаботинською на морд і знищення». (стор. 301).

Як бачимо зі слів: «банда», «морд», «вешталися», автор історик не $є$ прихильно наставлений до гайдамаків, але і він мусів признати, що причиною гайдамаччини було здирство польських панів, грабіжництво, гнів, московська провокація, себто, боротьба соціяльна для замаскування якої Польща 3 
Московщиною розпалювали релігійну ненависть. Натомість Московщина, використавши ситуацію політичного і соціального конфлікту Польщі для своїх політичних цілей, підбурила український народ до повстання іменем російської цариці, 3 iї ж наказу взяла участь в придушенні цього повстання, за що одержала в своє посідання від Польщі частину земель України.

Далі він пише: «Шляхта і пани, не бачучи нізвідки допомоги, ховалися по замках і більш збройних місцях. Зі всіх боків з’їздилися до Лисянки, Білої Церкви, а найбільше до Гуманя. Залізняк, довідавшись про те, постановив податися до тих військ і трьома ударами знищити всіх неприятелів-ворогів. Залізняк сам подався на Гумань, а в інші місця послав своїх підручних (Лисянка, Біла Церква, Гранів, Монастирище, Теплик, Дашів, Тульчин, Гайсин, Босівка, Жидачин, Ладижин). Міста були зруйновані, мешканці вирізані. Всі ці міста були вирізані вщент».

Найбільші події відбулися в м. Умані. От як їх описує той самий польський історик.

«Місто Умань було серцем маєтності Потоцького, що охоплювали Уманщину на 150 верств і одно 3 найбільших і найозброєніших в Західній Україні. Греки, армяни і жиди провадили в ньому багату торгівлю. В ньому жило 60 посесорів, що тримали на відкупі уманські добра і жили майже завжди в місті. В школі Василіян вчилося 400 учнів, 2600 козаків, утримуваних на кошти Потоцького, були охороною міста. До якого збіглося стільки жидів, що не могли уміститися в уманських хатах. Комісар графа, Младанович, одібравши у козаків присягу вірності, вислав їх проти козаків. Командувачем полку був полковник Обух (шляхтич польський), але головною особою був сотник Гонта. Потоцький любив Гонту і Гонта був до нього прихильний...

Гонта, вийшовши за границі Гуманщини, став обозом в степу і чекав на ворога. Наприкінці 3-го тижня прибули до Гонти посланці від Залізняка 3 пропозицією, щоб він злучився з ними. В цей час в м. Умані поширилася чутка, що Гонта сполучився з Залізняком. Панство вимагало від Младановича відкликання Гонти і покарання його на горло. Младанович викликав Івана 
Гонту і всіх сотників полку на нову присягу, яку ті під насильством мусіли скласти. Повернувшися до полку, вони стали по боці Залізняка.

Після виходу козаків проти Залізняка гарнізон міста складався лише 360 людей озброєних жидів, що стали на обороні стін. Незабаром з'явились війська Залізняка і Гонти, оточені повстанцями 3 народу. Вони негайно відкрили стрілянину на місто. Ректор школи Василіян закликав усіх до молитви і звелів дзвонити в усі дзвони. Повстанців зустріли картечним вогнем. Наступила ніч. На ранок знову розпочалися штурми і так тяглося кілька день. У місті забракло води i жагу гашено напоями. Скоро вийшли запаси пороху i гайдамаки вдерлися до міста. Вулиці залилися кривлею. Тут загинуло 15 тисяч людей. Той день відомий під назвою Уманської різні».

«Залізняк став обозом під Гуманем, де день і ніч його банда бенкетувала i оголосила його гетьманом України і князем Смілянським, а Гонту полковником і князем Гуманським».

«На придушення Гуманського повстання король Польщі вислав региментаря Стемпковського, а Катерина II (заступниця православних!) від себе генерала Керечетника з полком. Керечетник, що мав довір'я гайдамаків як союзник і як посланець цариці, яка вступилася за скривджених, був запроᄀшений до табору на бенкет і в часі бенкету обеззброїв гайдамаків, забрав 3 собою Залізняка, а Гонту разом 3 гайдамаками видав Стемпковському. Стемпковський стратив його в с. Сербах коло Бердичева».

Це оповідання про Уманську різню цілком розбігається 3 тим, що говорить український народ про цю подію і 3 тим, що фактично відомо 3 документальних джерел.

Що про цю подію думає український народ, найкраще ілюструють народні пісні, що збереглися в народніх устах з того часу. От що він співає про Максима Залізняка:

Літа орел, літа сизий попід небесами,

Гуля Максим, гуля батько степами, лісами.

Літа орел, літа сизий, а за ним орлята, 
Гуля Максим, гуля батько, а за ним хлоп'ята.

Народ також зберіг спогад про місто Умань в часі Уманської різні.

Максим козак Залізняк,

Козак Запорожжя,

Ой виїхав на Вкраїну,

Як повная рожа.

Обступили город Умань,

Поробили шанці

Та вдарили з сьоми гармат

У середу вранці

\section{МICTO ГУМАНЬ. МICTO У XVIII СТОРIЧЧI [Закінчення]} (Курінний, 1952/53)

Місто Умань XVIII сторіччя мало чим відрізнялося від того, яким воно було в XVII стор. Воно займало простір крутого коліна р. Гуманки між Гуманкою i яром Раковським. Річка захищала місто 3 півдня, заходу i південного сходу, а від півночі його межа по-старому йшла поздовж Красної вулиці і їі продовження - Софіївської. Простір Старого міста, або Старого базару, був оточений валом і палісадом, в якому було шестеро воріт-веж, з них дві $з$ гарматою. Вежі й ворота охороняла сторожа (60 осіб). Через ті ворота виходили шляхи: перший на південь - у степ, на Торговицю; другий - на Турок (селянське передмістя, де стояли 1671 турки з гетьманом П. Дорошенком); третя брама була звернена в бік Білогрудівки; четверта брама - Київська, найголовніша; п’ята - Красна, наприкінці Красної вулиці; шоста Звенигородська, що відкривала шлях на Звенигородку.

Як і в усіх старовинних українських селищах, хати стояли колом, залишаючи площу в середині міста вільною. На цій площі був «торг», стояли громадські будівлі (замок, Василіянський монастир, торговельні ряди, будинки адміністрації і війська). Просто повз вал оббігали вулиці стратегічного значення для підвозу бійцям припасів, руху допомогово[го] війська. Поздовж 
цих вулиць стояли кузні, майстерні, пекарні, склади припасів, доми охорони. Найважливішими історичними будовами, що їх згадано в подіях гайдамаччини, $€$ замок ратуша, Василіянський манастир, фарний костьол Миколая, критий ринок, кордегардія, хоральна синагога, доми козацької старшини, шляхти, купців, церква св. Михаїла. Місто було оточене селянськими передмістями: Раковкою, Турком, Лисою Горою, Звірками, Звенигородським, Івангородським, Полянецьким, Полігарнею, Звіринцем, Капказом. Міщанкою, Грековим Лісом, Білогрудівкою, Пиківцем.

1) Замок-ратуша з будинком губернатора Младановича був в північній частині міста між Київською та Білогрудівською брамами. Він був збудований у вигляді чотирикутника; в ньому містилися: двоповерховий будинок бароккового стиллю, з могутньою пивницею на два входи 3 двору і з вежею над будинком (нині вежа пожежної команди). Вікна були загратовані. Тут містилися управа губернатора, гуманського полку, ратуша, тримано військові припаси. Праворуч від воріт стояв житловий будинок губернатора (з цегли) на дві половини, він міг мати 5 покоїв, але тепер збереглися лише сіни та 4 покої. На ганкові цього будинку був забитий гайдамаками губернатор Младанович. Поруч дому були побудовані служби та конюшні губернатора та його охорони 3 гуманського полку.

2) Василіянський манастир i школа (потім Окружний суд). Це найпишніший будинок міста, вибудований як замок, 3 пишним під'їздом в центрі з внутрішнього боку двору i двома крилами, що закінчувалися порталами. Будинок двоповерховий з великою пивницею коридорної системи під усім будинком. На з'єднанні правого крила 3 центральними відділами будинку містилася простора церква в стилі клясицизму з колонадою, а під іiі вівтарем у склепах були поховання осіб з адміністрації школи. Тут стояли трупи, цвяхами був вибитий рік 1701. На похованих були одягнуті слуцькі паси. 3 цього можна бачити, що манастир і школа вже існували за часів Івана Мазепи.

В одній з камер пивниці манастиря знайшлася рушниця, на стволі, якої був сріблом вкований напис: «Тікай, бо біда». (Зберігається в Гуманському 
музеї). В школі вчилося 1768 року біля 400 учнів. Школа мала нумізматичний музей.

1773 року школа гостро поборювала замах ректора Краківської Академії Поплавського закрити доступ до науки в школі дітям українців. В садибі манастиря були будівлі для мешкання адміністрації, а сам манастир стояв у пишному парку французького стилю. На площі проти воріт манастиря була глибока криниця, куди було вкинуто частину забитих в час уманської різні.

Навкруги замку і школи-манастиря були приватні сади з будинками панів-посесорів та козацької старшини гуманського полку. Козаки гуманського полку стояли постоєм на передмістях м. Умані; їх було 2300 чоловіка кінних. Вони мали блакитно-жовті корогви, блакитні жупани 3 жовтими кунтушами $\mathrm{i}$ вильотами, блакитні широкі штани, кольорові чоботи, високі смушкові чорні шапки з жовтим шликом. Озброєння мали: шаблі, списи, рушниці, пістолі, a, крім того, козацьку снасть: ножі, натруски, порохівниці, мішечок 3 папушею тютюну, люльку та кресало. Місто мало герб - запорозький козак з рушницею. Отож Гуманщина колись була землею козацькою, запорізькою і тоді ж одержала свій давнішній герб, що згідно 3 царською постановою, був збережений у складі царського герба м. Умані. Царський герб мав вигляд щита, розділеного на три поля; вгорі велике, на ньому двоголовий орел, а внизу два малих: на одному запорозький козак, а на іншому герб аракчеєвських військових поселень (уланська шапка і два значки).

Фарний костьол св. Миколая, хоральна синагога, що досі збереглася, були колись стилю пізнього барокко з виразними українськими конструктивними деталями. Православний собор в Гумані титулу св. Михайла, стояв на ринкові (тепер вже знищений; $\epsilon$ лише посеред торгу каплиця). Був цегляний п’ятибанний. Збудований невідомо коли (чи не гетьманом Михайлом Ханенком?). Інші церкви зникли безслідно, крім дерев'яної церкви на: Звенигородському передмісті українського стилю, однобанної, з чудового малювання намісними образами XVIII стор. 
3 цивільних будинків треба відзначити два, що сягають безперечно часу уманської різні. Будинок т. зв. «аптеки» Калиновського, пишний палац, та будинок кордегардії - в'язниці 3 цегли, будований в типі української трикамерної хати з пивницею. Вал, палісад, брами і вежі міста не збереглися, i джерел до пізнання їх форм ми не маємо. Садиби козацької старшини, посесорів і заможних громадян були розкинуті по передмістях, але найбільше скупчено їх було в окремій частині міста - на Красній вулиці, серед пишних садків. Всі ці будинки української й польської шляхти були вибудовані на зразок українських трикамерних хат на 1-2 поверхи. Крамарі, ремісники жили в будівлях навколо базару в оригінальної архітектури заїздах.

Цвинтарі були далеко в полі за містом: жидівський - на Турку, православний - на Міщанці, католицький - на Київському шляху.

Отож на Гуманщині в XVIII стор. панує український архітектурний стиль; його зразками є: церква св. Михайла (5 бань), церква Івана Гонти в с. Росішках (3 бані), на Звенигородському передмісті (1 баня); будинки шляхти були трикамерного українського типу. До них долучалися бароккові будівлі замку, синагоги та приватні садибні доми. Осібно стоїть архітектура Василіянського манастиря, зразок європейської манастирської архітектури.

Вже після «уманської різні» граф С. Щенсний-Потоцький розбудував м. Умань поза межами старого міста. За стіни міста винесено палац графа, новий костьол, новий ринок та сад Софіївку.

Палац графа Потоцького був збудований 1793 року, фасадом він звернений до палацової площі. Садиба мала в пляні п’ятикутну форму. Палац стояв в глибині двору, оточений парканом пишного французького стилю, i оздоблений колонадою. Обабіч палацу під прямим кутом до нього, причілком до вулиці, стояли два одноповерхові флігелі й інші палацові служби.

3) Сад Софіївка. На північний схід від міста Умані, там, де розлогий яр Греків разом 3 урвистим річищем річки Кам'янки утворює трисагу - трикрилий амфітеатр з трьома ставками, розкинувся сад Софіївка, 
збудований графом Станіславом Щенсним-Потоцьким на честь своєї дружини грекині Софії.

Основою парку є круте узгір'я на п'ять терас 3 півночі і по чотири iз сходу i заходу, що всі збігаються зигзагуватими сходами до пишного павільйона на південному березі нижнього ставка.

Звідси до воріт парку, через дрімливий ліс вздовж течії річки, йде широка алея, обсаджена стрункими тополями. Цією дорогою пройшли незчислимі туристи, щоб милуватися красою парку, напитися води з цілющих джерел його (залізні, сірчано-кислі води), чи покоштувати знаменитих овочевих вин.

Весь парк складається 3 окремих декоративних груп рослин; кожна частина мала інший добір рослин і свій стиль, що надавали кожній частині своєрідности. Кожний із кутків Софіївки був оформлений за певного ідеєю, переважно з історичного минулого Греції - батьківщини Софії.

Вхід до парку стерегли дві круглі вежі. На правому високому узгір'ї, в лісі стояла альтанка-«грибок», за нею на мальовничій ясній поляні - будова діброва, присвячена Зевсові; ще далі над течією Кам’янки - Тарпейська Скеля. Далі шлях підходить до нижнього ставка 3 пишним павільйоном над ним, водограєм на 20 мтр., мальовничими пристанями, місточками, каскадою. Понад доріжками парку, що бігли вздовж ставка, були уміщені білі мармурові статуї Меркурія, Аполлона Бельведерського, Гомера, Платона, Сократа, чаша бога Ескулапа, лікаря 3 зміями, 3 якої бігла холодна вода 3 підземного джерела. Недалеко від неї, серед басейну з водою, стояла велика кам'яна ваза, повна квітів - приношення богині Діяні, а проти неї - могутня каскада, що падала 3 височини метрів у 20 (з вогкими переходами під нею), що переливалася на сонці чи у вечірніх вогнях феєрверків самоцвітами або відбивала веселку на хмарах туману над нею. Далі над самою серединою ставка, так що можна було бачити з усіх боків, була скеля; на ній стояла біломармурова постать Афродіти, що спускалася до води. Трохи далі за пишними квітучими кущами - мармурова постать Паріса, а на розгалуженні стежок - Купідон. 
Над касадкою, через Єлісейські Луки, стежки ведуть до іншого кута перебування богів Еллади, в якому серед різних мальовничих квітників де-не-де проглядають їх біломармурові постаті. При вході на поля вас зустрічає Аполлон Олімпійський, ще далі - присвячені богам чаші овочів і квітів, ще трохи далі кинута група «розбите життя» - гранітовка, надбита вгорі колона з надпаленим верхом, а біля їі підніжжя лежить природна поросла мохом скеля - «сплячий лев» - насправді дивовижний жарт природи. Ще далі - дві плити сірого уманського граніту під назвою - «природа та мистецтво». Одна штучно оброблена у вигляді могутнього моноліту стрункої форми 3 ідеально зашліфованими поверхнями, сторін, ребер і кутів. Друга - природна брила того ж граніту із мшистою поверхнею, випадково кинена на просторі зеленого лугу поруч першої. Кожному стає ясним, що природа і краса їі вища. Наприкінці «Слісейського Лугу» знаходиться храм Венери з ії жертовником і альтанкою Авгура (клітка для птиць) та басейн золотих рибок. Нарешті «громова» грота Зевса з вівтарем «вільної жертви» перед ним.

Храм Венери - дивовижний утвір архітектури і садового мистецтва. До шлюзу могутньої амстердамської дамби прибудовано імпозантний на чотири колони портик храму; з його фронтону пущено воду так, що вона падає тонким суцільним покровом перед колонадою на сходи і прикриває вхід наче прозорою завісою. За нею в середині храму на темному тлі стоїть мармурова постать Венери Купальниці. Від храму вода далі тече через ніжнозелений луг, на якому стоїть лицем до Венери Адоніс. Ще далі підходимо до «громової» або лев'ячої Гроти з вівтарем Зевсові. Вівтар - це стовп, на якому лежить велика брила каменю. В куті гроти з каменю б’є вода. Якщо похитати плиту вівтаря-стола, то чується спочатку віддалений грім, потім він стає сильнішим і наповнює печеру. На стіні гроти напис: «Хто увійшов сюди щасливим, вийде ще щасливішим». Ліворуч, біля входу до Гроти, колись стояв вівтар - Гранітовий постамент, на якому стояло бронзове вогнище. На ньому кожний міг запалити вогонь жертви. В садку ще в кількох місцях на вільному повітрі були такі жертовники для приношення богам квітів. 
За храмом Венери знаходиться верхній став 3 островом Венери i павільйоном, двома пристанями і спуском до купелі. Стрункі сріблясті тополі та верби оточують Іонійського стилю павільйон, що тоне в морі квітів.

Чудом паркової техніки був підземний тонель, що з'єднував став Венери 3 спеціальним басейном. Відвідувачі сідають в човни: на першому - оркестра, на другому - гості, мить - і шлюз відкритий: човни 3 музикою струнко зникають в підземельному тонелі, щоб за 10 хвилин виплисти в нижньому басейні.

Недалеко від храму Венери було ще Люстерко Діяни - глибока криниця, заглядаючи до якої можна було на глибині 7 метрів бачити себе на тлі неба в пишній декоративній круглій рамі $з$ дерев, та криниця, в якій голос відбивався багато разів і виразно повторював те, що ви хотіли собі почути.

Отож на гіперборейській півночі Гуманщини в XVIII стор. знову загорівся той вогонь, що був тут 2000 років перед тим, знову розквітли грецька і римська культура, їх мистецтво, література, чудові міти і поетична містика. Знову, бо 50 км. від Умані на схід в с. Журовці разом з грецькими вазами, що мають зображення грецької мітології і літературних сюжетів, знайшовся келих 3 надряпаним на ньому написом-присвятою богу Ескулапові, як і ваза цілющого джерела в Софії. В селі Новосильці виявлені на місцевій красуні-скитійці золоті оздоби з виображенням богинь і речей їх культу, а біля села Іллінець знайдено багате наруччя з золота із сценами 3 античної мітології - власність господаря уманського степу IV стор. до нашої ери.

3 переходом Уманщини до рук Московщини вона починає занепадати. Після знищення Запорозької Січі (1775) край залишився безборонним. Щоб створити собі захист проти українського населення, Москва закликала на козачі землі колоністів з Німеччини, Сербії тощо, а з українського хліборобського населення створила військові поселення за пляном графа Аракчеєва. Селяни в них жили з хліборобства, водночас відбуваючи військовий вишкіл і творячи військо. Села були перебудовані; хати були поставлені так, щоб селянина легко було викликати на муштру. Для військового начальства були побудовані в стилі 
українського ампіру затишні палаци (для начальників дивізій), доми для полкових урядовців тощо. Округовими центрами військових поселень стали Гумань та Маньківка. Ці міста були відповідно розбудовано і доми ці збереглися досі. Проте варварські були понищені будівлі XVII-XVIII стор., палац гр. Ст. Потоцького 3 галерією образів, а після польського повстання 1831 року і Софіївку було конфісковано і переіменовано на «Царицин сад». В парку було поставлено монумент на пошану царя й цариці. На Гуманщині посилилася панщина, школи було скасовано. Якщо в гуманській школі ще 1829 року викладалося для сотень дітей гуманської шляхти, міщанства i духівництва науки: релігію, мораль, російську та польську мови, вимову i поезію, літературу польську, латинську, грецьку, німецьку, французьку мови, городництво, каліграфію, географію, історію, геометрію, аритметику, алгебру, землемір'я, природознавство, фізику, мінералогію, хемію, технологію, - то вже в новій школі наука обмежувалася такими викладами: буквар, часословець, псалтир, російська історія, граматика, аритметика, географія. Кріпацтвом селянство було відсунуто від школи, проти чого ще в XVIII стор. боролися Василіяни. Селянину залишено було лише стару дяківську школу. Це значно знижувало широчінь старої козачої освіти і зводило вихованців цієї школи на найнижчі ступені в урядовій службі в своєму краю. На вищих урядовців і командирів війська надіслано москалів і сербів, що зайнялися московізацією краю. Після відібрання Софіївки від гр. Ст. Потоцького в саду було відкрито школу садівництва i хліборобства, що постачала агрономів та управляючих маєтками на всю колишню Росію та Польщу.

В другій половині XIX стор. в Умані почала вже діяти стара громада на чолі з нотарем Михайлом Комаровим «Уманець і Спілка», що випускала для народу популярні книжки, провадила читання, досліди мови, звичаїв, переклади на українську мову Святого Письма. Трудами їх 3’явився друком словник української мови «Уманця і Спілки», що досі є незамінимим джерелом пізнання нашої мови. Гурток Комарова заступила стара громада нотарів; до неї належали: лікар Ю. Крамаренко, адвокат П. Курінний, лікар П. Стаховський, 
священик Макар Крамаренко та інші. 3 гуманських шкіл вийшли такі видатні діячі української культури, як митрополит Василь Липківський, академік Микола Біляшівський, академік Сергій Сфремов, проф. Василь Данилевич, кооператор В. Доманицький, Х. Барановський, Співецький, проф. Демуцький, Іван Олексіїв і багато інших.

На початку революції в 1917 році м. Умань було сильним культурним осередком українського національного життя. Крім повітових, громадських та адміністративних установ та організацій (земства), тут діяв Кооперативний Союз, Позичково-ощадне Т-во, виходило кілька часописів («Союз), тижневик «Громадське життя».

3 шкіл тут працювали: Школа хліборобства і садівництва, Кооперативний технікум, Технікум будівельний, Керамічний, Народного мистецтва, три українські гімназії, повна сітка народних шкіл. Український Народний Університет, Курси готування учителів, повна сітка просвіт, Історичний Музей Уманщини, Дослідна агрономічна станція, Музеї природничий та санітарний, Духовна школа.

В м. Умані був завод сільськогосподарських машин.

Місто Умань мало на час появи большевиків 9 церков, 2 синагоги, 1 костьол, 3637 будинків, населення 45.343, з них жидів 49,5, росіян 4,6, поляків 1,7 .

3 приходом московського большевизму всі національні установи були знищені або перетворені на большевицькі; діячі частково розстріляні, інші заслані, а населення, що боролося за вільний творчий труд, знищено голодом, заслане поза межі краю. Край, знову загнаний до кріпацтва, став країною колоніального визиску чужинцями.

\section{СПИСОК ВИКОРИСТАНИХ ДЖЕРЕЛ І ЛІТЕРАТУРИ}

Білокінь, 1998 - Білокінь С. Курінний П.П. // Вчені Інституту історії України: Бібліографічний довідник. К. 1998. C. $170-172$.

Курінний, 1952 - Курінний П. П. Місто Гумань // Авантард.1952. Ч 3 (25). С. 11-12.

Курінний, 1952/53 - Курінний П. П. Місто Гумань // Авантард.1952/53. Ч 4-5 (26-27). С. 13-18.

Пекарська, 2009 - Пекарська Л. В. Петро Курінний: повернення із забуття // Тематичний збірник наукових праць Наиіонального музею історії України. Ч. 2. К. 2009. С. 94-105. 
Станіцина, 2015 - Станиціна Г. Особисте листування науковців як джерело свідчення про становище населення України у 20-ті - на початку 30-х років XX ст. (за матеріалами Наукового архіву Інституту археології НАН України) // Матеріали і дослідження з археологї̈ Прикарпаття і Волині. 2015. Вип. 19. С. 170-180.

Торгало, 2014 - Торгало Ю. Петро Петрович Курінний. Умань. 2014. 134 с.

\section{REFERENCES}

Bilokin, 1998 - Bilokin S. Kurinnyi P.P.//Vcheni Instytutu istorii Ukrainy: Bibliohrafichnyi dovidnyk. [Scientists of the Institute of History of Ukraine: bibliographic guide]. K. 1998. S. 170-172. [in Ukrainain].

Kurinnyi, 1952 - Kurinnyi P. P. Misto Human [City of Guman] // Avangard.1952. Ch 1 (23). S. 12-14. [in Ukrainain]. Kurinnyi, 1952 - Kurinnyi P. P. Misto Human [City of Guman] // Avangard.1952. Ch 2 (24). S. 15-17. [in Ukrainain]. Pekarska, 2009 - Pekarska L. V. Petro Kurinnyi: povernennia iz zabuttia [P. Kurinnyi: Return from oblivion] // Tematychnyi zbirnyk naukovykh prats Natsionalnoho muzeiu istorii Ukrainy. Ch. 2. K. 2009. S. 94-105. [in Ukrainain]. Stanitsyna, 2015 - Stanytsina H. Osobyste lystuvannia naukovtsiv yak dzherelo svidchennia pro stanovyshche naselennia Ukrainy u 20-ti - na pochatku 30-kh rokiv KhKh st. (za materialamy Naukovoho arkhivu Instytutu arkheolohii NAN Ukrainy) [Personal correspondence of scientists as a source of evidence of the situation of the population of Ukraine in the 20's - in the early 30's of the twentieth century. (based on the materials of the Scientific Archive of the Institute of Archeology of the National Academy of Sciences of Ukraine)] // Materialy i doslidzhennia z arkheolohii Prykarpattia i Volyni. 2015. Vyp. 19. S. 170-180. [in Ukrainain].

Torhalo, 2014 - Torhalo Yu. Petro Petrovych Kurinnyi. [Petro Petrovich Kurinnyi]. Uman. 2014. 134. [in Ukrainain]. 